\title{
Effect of Environmental Stressors on the mRNA Expression of Ecdysone Cascade Genes in Chironomus Riparius.
}

\section{Mercedes de la Fuente}

UNED: Universidad Nacional de Educacion a Distancia

Raquel Martín Folgar ( $\nabla$ mfolgar@ccia.uned.es )

UNED: Universidad Nacional de Educacion a Distancia

\section{Pedro Martínez-Paz}

UNED: Universidad Nacional de Educacion a Distancia

\section{Estrella Cortés}

UNED: Universidad Nacional de Educacion a Distancia

José Luis Martínez-Guitarte

UNED: Universidad Nacional de Educacion a Distancia

Mónica Morales

UNED: Universidad Nacional de Educacion a Distancia

\section{Research Article}

Keywords: Endocrine-disrupting chemicals (EDCs), Chironomus riparius, toxicity, transcriptional response

Posted Date: May 17th, 2021

DOI: https://doi.org/10.21203/rs.3.rs-451048/v1

License: (c) (i) This work is licensed under a Creative Commons Attribution 4.0 International License.

Read Full License 


\section{Abstract}

Chemical compounds produced by humans are continuously reaching the environment. In this work, we characterised the expression patterns of important endocrine-related genes involved in the ecdysone pathway in the fourth larval instar of the model species Chironomus riparius after exposure to three chemicals: ethinyl oestradiol (EE), nonylphenol (NP) and bis(tributyltin) oxide (TBTO). We used real-time PCR to analyse the gene expression levels of: ecdysone receptor (ECR) and ultraspiracle (usp), two genes that encode the dimerising partners of the functional ecdysone receptor; the orphan receptor $E R R$ (oestrogen-related receptor), with an unknown function in invertebrates; and $E 74$, an early response gene induced by ecdysteroids. We estimated the bioaccumulation potential, bioavailability and physicochemical properties of these chemicals, together with a number of other exogenous agents known to interfere with the hormonal system. We also provide a review of previous transcriptional studies showing the effect of all these chemicals on ecdysone cascade genes. This analysis provides useful data for future ecotoxicological studies involving invertebrate species.

\section{Highlights}

- The gene expression patterns reveal different molecular mechanisms of toxicity.

- Endocrine-disrupting chemicals do not always elicit same effects as natural hormone.

- This work highlights the importance of the kinetics of the gene expression response.

- EcR, E74, usp and ERR genes are valuable markers of toxicity mechanisms.

\section{Capsule}

Changes in transcriptional activities of ECR, E74, usp and ERR genes after exposure to endocrinedisrupting chemicals would be useful as molecular bioindicators of endocrine disruption in Chironomus riparius.

\section{Introduction}

Endocrine-disrupting chemicals (EDCs) are substances that alter a wide variety of physiological, biochemical and/or molecular processes in an organism by interfering with the regulatory networks of endogenous hormones. The impacts of the disruption are quite diverse and involve development, growth, reproduction, neurological and immune processes (Cuvillier-Hot and Lenoir, 2020). Beyond the influences that these effects have on worldwide biodiversity, the characterisation of EDC responses in invertebrates is tremendously interesting and widely recognised among environmental toxicologists due to the central role of invertebrate species in ecosystems and, consequently, to their importance in ecotoxicological testing and for monitoring environmental conditions. Toxicity testing provides information about the physiological effects of toxicants, but there is still a gap with regard to the mechanisms of action of the 
toxicant and the response of the organism at the cellular and molecular levels. In this sense, the changes in transcriptional activities of several selected genes after exposure to EDCs have proven to be a very useful tool as molecular bioindicators of endocrine disruption in aquatic invertebrates (Kim et al., 2015; Poynton and Vulpe, 2009). Chironomus riparius is considered a convenient and suitable model organism for these ecotoxicological assessments. The United States Environmental Protection Agency (US EPA), Organization for Economic Co-operation and Development (OECD) and the American Society for Materials Testing (ASTM) have published standardised protocols for the development of toxicity tests with these insects (ASTM, 2006; OECD, 2004, 2010, 2011). Accordingly, myriad studies have been performed to distinguish the effects of different environmental pollutants on the expression of genes of interest in this insect (Aquilino et al., 2016; Herrero et al., 2017, 2018; Martínez-Paz et al., 2012, 2017; Morales et al., 2013, 2014, 2020; Nair and Choi, 2012; Nair et al., 2013; Ozáez et al., 2013, 2014, 2016; Park and Kwak, 2010; Planelló et al., 2007, 2008, 2010, 2011, 2015).

It is essential to have accumulated knowledge regarding the putative mode of action of EDCs to choose the best biomarkers, to standardise the transcriptional studies for toxicity test and to allow the extrapolation of the observed effects to wildlife. Different molecular regulatory pathways have been revealed to be susceptible to endocrine disruption, some of which are specific to invertebrates. In $C$. riparius, one of the primary hormonal pathways susceptible to alteration is that triggered by 20 hydroxiecdysone (20E) (Cuvillier-Hot and Lenoir, 2020), one of the main steroid hormones in insects. Previous studies carried out in salivary glands exposed to $20 \mathrm{E}$ under a variety of conditions demonstrated the molecular basis of 20E action in Drosophila melanogaster. In the early 1970s, Ashburner (1974) proposed that $20 \mathrm{E}$ binds to the ecdysone receptor $(\mathrm{EcR})$, which is the ecdysone receptor/ultraspiracle (EcR/USP) heterodimer (Koelle et al., 1991; Lezzi et al., 1999; Yao et al., 1993). The 20E receptor complex differentially regulates a multitiered hierarchy of responses involving several classes of 'early' and 'late' genes, so that it activates the expression of the early genes (whereas a receptor without ligand acts as a repressor) and represses the late ones. The protein products of the early genes are transcription factors that derepress the expression of the late gene transcription and, concomitantly, repress their own expression. The late genes encode the proteins responsible for the temporal and tissue-specific responses in target tissues (Dhadialla et al., 2005; Karim and Thummel, 1992; Nakagawa and Henrich, 2009; Uyehara and McKay, 2019). The wide array of assays performed in C. riparius exposed to several chemicals, referenced above, have analysed the up/downregulation of some genes belonging to this so called 'ecdysone cascade' - most of them involve ECR, usp, and $E 74$ genes, as well as oestrogen-related receptor $(E R R)$, whose function is not fully understood but whose activation seems very relevant during developmental stages (Bunce and Campbell, 2010).

Despite the accumulated information, additional work is required to ascertain the effect of each pollutant. This work requires molecular data combined with other aspects such as the bioaccumulation and the elimination of the compounds. The aim of this work is to combine the data obtained for transcriptional activity, from the literature and for additional toxicants studied here, with the properties of the compounds to provide a broader view of the EDCs (see Supplementary material) as agonists/antagonists of hormonal receptors. 


\section{Materials And Methods \\ 2.1. Animals and treatments}

Fourth instar $C$. riparius larvae served as the experimental model organism. They were maintained under constant aeration at $19 \pm 1^{\circ} \mathrm{C}$ and under $16: 8 \mathrm{~h}$ light-dark photoperiods for several generations according to toxicity testing guidelines (OECD-EPS). Larvae were maintained in culture medium $\left(0.5 \mathrm{mM} \mathrm{CaCl}_{2}, 1\right.$ $\mathrm{mM} \mathrm{NaCl}, 1 \mathrm{mM} \mathrm{MgSO}_{4}, 0.1 \mathrm{mM} \mathrm{NaHCO}_{3}, 0.025 \mathrm{mM} \mathrm{KH}_{2} \mathrm{PO}_{4}, 0.01 \mathrm{mM} \mathrm{FeCl}_{3}$ ) supplemented with nettle leaves, fish feed and cellulose paper. The larvae were exposed to the chemical compounds diluted in culture medium for 24 and $96 \mathrm{~h}$ with constant aeration at $19 \pm 1^{\circ} \mathrm{C}$ (Martínez-Paz et al., 2012). We selected doses based on results from previous studies in $C$. riparius and other arthropods. Fourth instar larvae were submitted to $0.05,0.5$ and $5 \mathrm{mg} / \mathrm{L}$ ethinyl estradiol (EE) (Sigma-Aldrich); 1,10 and $100 \mu \mathrm{g} / \mathrm{L}$ p-nonylphenol (NP) (Sigma-Aldrich); and 0.1, 1, 10, 100 and $1000 \mathrm{ng} / \mathrm{L}$ bis(tributyltin) oxide (TBTO)

(Sigma-Aldrich). Each treatment comprised three replicates and there were three independent experiments in each analysis using samples from three different control egg masses. The control larvae used in each case were exposed to the same solvent concentration as the corresponding treatment and were also measured in triplicate. After the exposure, larvae were stored at $-80^{\circ} \mathrm{C}$ until RNA isolation was carried out.

\subsection{RNA isolation and reverse transcription}

We isolated RNA and generated complementary DNA (CDNA) by reverse transcription following the procedures of previous works (Martínez-Paz et al., 2012, 2014, 2017; Morales et al., 2013, 2014).

\subsection{Real-time PCR}

We used cDNA as the template for real-time PCR to analyse the mRNA expression profile of $E c R, E 74$, usp and $E R R$ genes in control and treated samples. The sequences of all gene-specific primers used in this study are indicated in Table 1. We used $\beta$-Actin, Glyceraldehyde 3-phosphate dehydrogenase (GAPDH) and ribosomal protein $\angle 13(r p L 13)$ as reference genes to normalize the transcript expression of target genes (Martínez-Guitarte et al., 2007). The reference genes presented a coefficient of variation $<0.25$ and an M-value < 0.5 (Hellemans et al., 2007). We used real-time PCR conditions from a previous study (Martínez-Paz et al., 2017).

Table 1. Primers used for real-time PCR amplification from Chironomus riparius. 


\begin{tabular}{|lll|}
\hline Oligonucleotide & Sequence $\left(\mathbf{5}^{\prime}\right.$ - $^{\prime}$ ) & Melting temperature \\
\hline Actin F & GATGAAGATCCTCACCGAACG & $65.8^{\circ} \mathrm{C}$ \\
\hline Actin R2 & CGGAAACGTTCATTACCG & $61.5^{\circ} \mathrm{C}$ \\
\hline GAPDH F & GGTATTTCATTGAATGATCACTTTG & $62.1^{\circ} \mathrm{C}$ \\
\hline GAPDH R & TAATCCTTGGATTGCATGTACTTG $^{\circ}$ & $63.6^{\circ} \mathrm{C}$ \\
\hline L13 F & AACGTGCTTTCCCAAGAC & $60.3^{\circ} \mathrm{C}$ \\
\hline L13 R & TTGGCATAATTGGTCCAG & $59.5^{\circ} \mathrm{C}$ \\
\hline EcR rt F & CCATCGTCATCTTCTCAG & $56.5^{\circ} \mathrm{C}$ \\
\hline EcR rt R & TGCCCATTGTTCGTAG $^{\circ}$ & $56.3^{\circ} \mathrm{C}$ \\
\hline USP F & GCCCAATCATCCGTTAAGTGG & $67.3^{\circ} \mathrm{C}$ \\
\hline USP R & CGTTTGAAGAATCCTTTACATCC & $62.4^{\circ} \mathrm{C}$ \\
\hline ERR F & CTCAGCAAGTAAGGAGGAG & $57.7^{\circ} \mathrm{C}$ \\
\hline ERR R & CGTCTAATAATGTGATCGG & $55.5^{\circ} \mathrm{C}$ \\
\hline E74 F & TCTTACTGAAACTTCTTCAAGATCG $^{\circ}$ & $61.6^{\circ} \mathrm{C}$ \\
\hline E74 R & GCTTTGAGACAGCTTTGGAATCG & $67.9^{\circ} \mathrm{C}$ \\
\hline
\end{tabular}

\subsection{Statistical analysis}

We compared between the control and the treated larvae using analysis of variance (ANOVA) with Dunnett's multiple comparison tests. We normalised ECR, E74, usp and ERR mRNA levels against the expression of the reference genes ( $\beta$-Actin, GAPDH and $r p L 13)$ in the same samples. We used SPSS 22.0 software (IBM) for statistical analysis. We checked the data for a normal distribution and variance homogeneity using the Kolmogorov-Smirnov test and Levene's test, respectively. We considered a difference to be significant at $\mathrm{p}<0.05$.

\subsection{Molecular descriptors, principal component analysis (PCA) and hierarchical clustering analysis (HCA)}

We calculated the molecular weight and volume, as well as other molecular structure indicators, solvation properties (such as the aqueous solubility, [log S] and the octanol-water partition coefficient [log P]) and the bioconcentration factor (BCF) using the following software: molinspiration (Molinspiration Cheminformatics free web services, n.d.), EPI Suite (US EPA, 2020) and eDragon (http://www.vcclab.org/lab/edragon/; Tetko et al., 2005). We analysed the estimated values with PCA and HCA, using ClustVis (Metsalu and Vilo, 2015; https://biit.cs.ut.ee/clustvis/).

\section{Results And Discussion}




\subsection{Transcriptional response of the EcR gene under different exposures to chemical compounds}

We examined the effects of 24 and $96 \mathrm{~h} \mathrm{EE,} \mathrm{NP} \mathrm{and} \mathrm{TBTO} \mathrm{exposure} \mathrm{on} \mathrm{EcR} \mathrm{expression} \mathrm{in} \mathrm{C.} \mathrm{riparius}$ fourth instar larvae using real-time PCR. Twenty-four hours exposure to $5 \mathrm{mg} / \mathrm{L}$ EE and $96 \mathrm{~h}$ exposure to $0.5 \mathrm{mg} / \mathrm{L} \mathrm{EE}$ increased EcR mRNA levels (Fig. 1A). Exposure to $5 \mathrm{mg} / \mathrm{L} \mathrm{EE}$ for $96 \mathrm{~h}$ was lethal for the larvae, so there is no data with regard to $E c R$ expression. There was a significant decrease in $E c R$ expression in larvae exposed to $100 \mu \mathrm{g} / \mathrm{L}$ NP for $24 \mathrm{~h}$ (Fig. 1B). However, mRNA levels were increased after $96 \mathrm{~h}$ exposure to 1 and $10 \mu \mathrm{g} / \mathrm{L} \mathrm{NP}$ (Fig. 1B). TBTO exposure increased EcR expression, doubling the levels found in control larvae. The effect was evident at $24 \mathrm{~h}$ for $1 \mathrm{ng} / \mathrm{L}$ TBTO and at $96 \mathrm{~h}$ for 1 and 10 ng/L TBTO (Fig. 1C).

The impact of several pollutants in the transcriptional activity of $E C R$ has been widely studied (Herrero et al., 2015, 2017, 2018; Martínez-Paz et al., 2012, 2017; Morales et al., 2013, 2014, 2020; Nair and Choi, 2012; Nair et al., 2013; Ozáez et al., 2013, 2014, 2016; Planelló et al., 2007, 2008, 2010, 2011, 2015; Xie et al., 2019). This gene encodes a key regulator in the ecdysone-inducible gene activation cascade in insects (Huet et al., 1995; Shirai et al., 2012). Its responsiveness makes it particularly relevant in toxicological studies, and it is considered a suitable environmental biomarker. Exposure to most of the organic compounds that have been studied causes an early upregulation of the $E c R$ gene, mimicking the response of this gene to the ecdysteroid hormone 20E. Moreover, studies performed at different times with fourth instar larvae treated with the fungicide vinclozolin (VZ) have shown $E c R$ upregulation at $24 \mathrm{~h}$, followed by a return to control levels at $48 \mathrm{~h}$ (Aquilino et al., 2016). This sequential behaviour is similar to that observed in the presence of $20 \mathrm{E}$ (Ozáez et al., 2014). The main chemicals that do not induce the aforementioned effect include di(2-ethylhexyl) phthalate (DEHP) and butyl benzyl phthalate (BBP) (Herrero et al., 2015, 2017) - both causing ECR downregulation at longer exposure times; and bisphenol $\mathrm{F}$ (BPF), benzophenone-3 (BP-3), 4hidroxybenzophenone (4-HB), octocrylene (OC) and DEHP - all of which do not alter $E c R$ expression after short-term treatment $(24 \mathrm{~h})$ (see Supplementary material). All these compounds are proven endocrinal disruptors, but according to these results they do not mimic the $20 \mathrm{E}$ effects.

The results of the test performed with the oestrogen analogue EE (Fig. 1A) and with the organometallic compound TBTO (Fig. 1C) allow us to add them to the group of compounds that upregulate EcR. The gene is upregulated from either short- or long-term of exposure, revealing a different mode of action of this substance relative to VZ and 20E (see Supplementary material).

On the contrary, NP upregulated EcR at the lowest dosage and the longer exposure time (Fig. 1B), showing a dose-dependent behaviour inverse to that of EE and TBTO. The EcR was significantly increased upon exposure to different concentrations of NP $(0.01$ and $0.05 \mathrm{mg} / \mathrm{L})$ in a dose- and timedependent manner (Nair and Choi, 2012). Testing a wider range of concentrations, an inverse relation between dose and expression became apparent: this gene was even downregulated at a higher NP dose $(0.1 \mathrm{mg} / \mathrm{L})$ and a shorter exposure time $(24 \mathrm{~h})$. By contrast, previous studies revealed a significant 
increase in $E R R$ mRNA expression in C. riparius larvae exposed to the same dosages $(1,10$ and $100 \mu \mathrm{g} / \mathrm{L})$ of NP for $24 \mathrm{~h}$ and $96 \mathrm{~h}$ (Park and Kwak, 2010). To confirm the different behaviour of ECR and ERR expression in the presence of NP, we carried out a new set of experiments with the same conditions that we used to evaluate $E c R$ expression. There was no $E R R$ upregulation, as had been previously reported. On the contrary, exposure to $100 \mu \mathrm{g} / \mathrm{L}$ NP for $24 \mathrm{~h}$ inhibited ERR expression (Fig. 2). The response was quite similar to that found for $E C R$; this finding could suggest some kind of relationship between both receptors in the response to NP.

In summary, based on these results, there are different patterns of response when $E c R$ is analysed, suggesting that there is a different underlying molecular mechanism of toxicity for the studied EDCs. The importance of the kinetics of the response at the molecular level is highlighted by the present results. Hence, future work should assess the effect at different treatment times and at several sub-lethal dosages, an endeavour that could help to identify the specific pattern of changes for each compound in relation to EcR transcription.

\subsection{Transcriptional response of other ecdysone pathway genes after long-term TBTO exposure}

Steroid hormones exert their effects via nuclear hormone receptors that directly regulate the transcription of target genes. EcR and E74 are key regulators in the ecdysone-inducible gene activation cascade in insects (Huet et al., 1995; Shirai et al., 2012). They are 'early' genes because they are directly induced by $20 \mathrm{E}$ as a first response. Their products activate the transcription of a few early-late genes, inactive their own transcription and further induce hundreds of late genes. The EcR/USP heterodimer regulates the expression of $E C R$ and $E 74$ genes through binding to the ecdysone response element in their promoter region. The mRNA levels for usp, the other component of the ecdysone receptor heterodimer, remain essentially unchanged during the different developmental stages (Huet et al., 1995). This behaviour could be observed for these three genes in salivary glands of C. riparius triggered by ecdysone (Ozáez et al., 2014): in response to 20E exposure, the ECR gene was overexpressed earlier, E74 expression was slightly retarded and there was no alteration in usp expression. Accordingly, these three genes together with the $E R R$ gene have shown an ability to detect endocrine-disrupting activities in invertebrates and to define putative different mode of actions for each EDC. The effect of short-term TBTO exposure on the expression of these four genes has been reported (Morales et al., 2013). To improve our knowledge about TBTO exposure and its putative molecular mechanism of toxicity, we examined the effects of long-term (96 h) TBTO exposure on ERR, E74 and usp expression in C. riparius fourth instar larvae using real-time PCR (Fig. 3). Only exposure to $1 \mathrm{ng} / \mathrm{L}$ induced significant usp overexpression. E74 and ERR expression was not altered in any studied condition. By contrast, $E 74$ and $E R R$ genes are overexpressed after $24 \mathrm{~h}$ exposure (Morales et al., 2013). The ability of TBTO to induce usp expression shows a different behaviour compared with most other EDCs that have been tested in C. riparius (Planelló et al., 2008, 2011, 2015; Ozáez et al., 2013; Morales et al., 2014). Therefore, these data suggest that TBTO acts as endocrine disruptor but does not mimic the hormone ecdysone, because it can upregulate $E c R, E 74, E R R$ and usp 
after a $24 \mathrm{~h}$ exposure, while it only upregulates $E c R$ and $u s p$ gene after $96 \mathrm{~h}$. We observed similar behaviour only after short-term triclosan/5-chloro-2-(2,4-dichlorophenoxy) phenol exposure (Martínez-Paz et al., 2017). Consequently, assessing the effect of EDCs on the transcription of all these four genes is interesting to reveal and classify different putative molecular mechanisms of toxicity.

\subsection{Bioaccumulation potential, bioavailability and physicochemical properties of EDCs: PCA and HCA analysis}

We obtained several descriptors from in silico analysis to gather information about potential bioconcentration, bioavailability and a quantitative description of molecular structure for all the chemical compounds we explored in this work. The toxicity of EDCs should mostly be interpreted from the standpoint of its mode of action and the body burden in aquatic insects (Katagi and Tanaka, 2016). So that we might have a fuller picture of their effect, it is of interest to estimate the bioaccumulation potential and the bioavailability of the studied EDCs, as indicators of the putative body burden (Lai et al., 2002). The molecular lipophilicity - which is quantitively described by the octanol-water partition coefficient, represented by $\log \mathrm{P}$ for neutral compounds - is one of the most important physicochemical properties that affects the bioavailability of compounds and it can be useful to estimate in vivo permeability. Hence, it can be used to understand bioaccumulation and exposure of wildlife to environmental pollutant (Bhal, n.d.; Zhang et al., 2018).

Very lipophilic substances $(\log P>5)$ are generally considered to have the greatest potential to bioaccumulate (without further consideration about metabolism or degradation), whereas substances with low lipophilicity $(\log P<2)$ have relatively low bioaccumulation potential. On the other hand, the bioconcentration and bioaccumulation factors (BCF and BAF, respectively) are indicators that can be used to predict the bioaccumulation potential. It was proposed that there is not significantly bioaccumulation for $\mathrm{BCF}$ or $\mathrm{BAF}<1,000$ and the bioaccumulation is high for $\mathrm{BCF}$ or $\mathrm{BAF}>5,000$ (National Research Council, 2014). Thus, as can be seen in Fig. 4, very low bioaccumulation potential can be expected for SDZ and BPS, whereas, at the other end, 4MCB would be highly bioaccumulative.

Furthermore, bioavailability is a measure of the amount of a chemical that can contact biological barriers and the rate at which it crosses and enters the organism to interfere tentatively in biological processes. While a lack of bioavailability is an indicator that the compound is likely to have low toxicity, high bioavailability does not suggest the compound is necessarily highly toxic. In aquatic species, bioavailability is positively correlated with the $\log \mathrm{P}$ of the chemical; it is also influenced by aqueous solubility, molecular size and ionisation state. As molecular weight increases, aquatic bioavailability and toxicity generally decrease, where bioavailability is negligible at a molecular weight $>1000 \mathrm{amu}$ and very poorly water-soluble chemicals ( $<1 \mathrm{ppb}$ ) generally have low bioavailability and are less toxic (National Research Council, 2014). Figure 5 shows a putative estimation of the bioavailability, considering the $\log P$ (lipophilicity), $\log \mathrm{S}$ (aqueous solubility) and molecular sizes for the analysed chemical compounds. Based on these results, the compounds with a bioavailability most similar to $20 \mathrm{E}$ are SDZ, BPS, VZ and BPF. 
Once inside cells, the biochemical behaviour and inherent toxicity of a chemical are dependent of its intrinsic physicochemical properties (National Research Council, 2014). The hydrophobicity, the polarity, the number of putative hydrogen bond acceptor/donor groups, the flexibility and the molecular size are all key attributes that determine the interaction between a chemical and its targets. Some molecular descriptors enable us to quantify these characteristics for each compound. Thus, we calculated selected descriptors by applying several methods (see Supplementary material): the molecular weight and volume, the topological polar surface area (TPSA), the octanol-water partition coefficient (P), the hydrogen bond acceptor/donor count, the hydrophilic factor, the aqueous solubility coefficient (log $S$ ), the number of rotatable bonds and the unsaturated index. To classify the chemical compounds based on these properties, we employed PCA and HCA. The results of these analysis are included in Supplementary Materials and are summarised in Fig. 6. Given that EDCs represent a broad class of molecules with divergent modes of action, this classification provides us with a convenient grouping to evaluate more easily their different effects on gene expression changes through their putative interaction with nuclear receptors. Consequently, we compiled the main previously reported experimental results showing the transcriptional activity changes of the ecdysone cascade genes $E c R, E 74$, usp and $E E R$ in response to EDC exposure (Table 2); we sorted the gathered information according to this EDC classification.

Table 2. In vivo exposure effects of endocrine-disrupting chemicals on fourth instar larvae of Chironomus riparius 


\begin{tabular}{|c|c|c|c|c|c|c|c|c|c|}
\hline \multirow[t]{2}{*}{ Chemical } & \multicolumn{2}{|l|}{$E c R$} & \multicolumn{2}{|l|}{ usp } & \multicolumn{2}{|l|}{$E 74$} & \multicolumn{2}{|l|}{$E R R$} & \multirow[t]{2}{*}{ References } \\
\hline & Effect & $\begin{array}{l}\text { Chemical } \\
\text { exposure }\end{array}$ & Effect & $\begin{array}{l}\text { Chemical } \\
\text { exposure }\end{array}$ & Effect & $\begin{array}{l}\text { Chemical } \\
\text { exposure }\end{array}$ & Effect & $\begin{array}{l}\text { Chemical } \\
\text { exposure }\end{array}$ & \\
\hline \multicolumn{10}{|l|}{ Group 1} \\
\hline BPS & 1 & $\begin{array}{l}24 \mathrm{~h} \\
\geq 0.005 \mathrm{mg} / \mathrm{L}\end{array}$ & \multicolumn{2}{|l|}{$\mathrm{N} / \mathrm{A}$} & 산 & $\begin{array}{l}24 \mathrm{~h} \\
1 \mathrm{mg} / \mathrm{L} \\
\end{array}$ & 술 & $\begin{array}{l}24 \mathrm{~h} \\
\geq 0.005 \mathrm{mg} / \mathrm{L}\end{array}$ & $\begin{array}{l}\text { (Herrero et al., 2018; } \\
\text { Morales et al., 2020) }\end{array}$ \\
\hline SDZ & 수 & $\begin{array}{l}48 \mathrm{~h} \\
0.002 \mathrm{mq} / \mathrm{L} \\
\end{array}$ & \multicolumn{2}{|l|}{$\mathrm{N} / \mathrm{A}$} & 삼 & $\begin{array}{l}48 \mathrm{~h} \\
0.002 \mathrm{mq} / \mathrm{L}\end{array}$ & \multicolumn{2}{|l|}{$\mathrm{N} / \mathrm{A}$} & (Xie et al., 2019) \\
\hline \multirow{2}{*}{ VZ } & 1 & $\begin{array}{l}24 \mathrm{~h} \\
0.02 \mathrm{mg} / \mathrm{L}\end{array}$ & \multirow{2}{*}{\multicolumn{2}{|c|}{$\mathrm{N} / \mathrm{A}$}} & $\equiv$ & $\begin{array}{l}24 \mathrm{~h} \\
0.02 \text { and } 0.2 \\
\mathrm{mg} / \mathrm{L}\end{array}$ & \multirow{2}{*}{\multicolumn{2}{|c|}{$\mathrm{N} / \mathrm{A}$}} & \multirow{2}{*}{ (Aquilino et al., 2016) } \\
\hline & $\equiv$ & $\begin{array}{l}48 \mathrm{~h} \\
0.02 \text { and } 0.2 \\
\mathrm{mg} / \mathrm{L}\end{array}$ & & & - & $\begin{array}{l}48 \mathrm{~h} \\
0.02 \mathrm{mg} / \mathrm{L}\end{array}$ & & & \\
\hline \multicolumn{10}{|l|}{ Group 2} \\
\hline BPF & 수 & $\begin{array}{l}24 \mathrm{~h} \\
\geq 0.05 \mathrm{mg} / \mathrm{L}\end{array}$ & \multicolumn{2}{|l|}{$\mathrm{N} / \mathrm{A}$} & 삼 & $\begin{array}{l}24 \mathrm{~h} \\
1 \mathrm{mg} / \mathrm{L}\end{array}$ & \multicolumn{2}{|l|}{$\mathrm{N} / \mathrm{A}$} & (Morales et al., 2020) \\
\hline BPA & - & $\begin{array}{l}12 \text { and } 24 \mathrm{~h} \\
\geq 3 \mathrm{mg} / \mathrm{L}\end{array}$ & \multicolumn{2}{|l|}{$\mathrm{N} / \mathrm{A}$} & $\equiv$ & $\begin{array}{l}24 \mathrm{~h} \\
\geq 0.05\end{array}$ & 슬 & $\begin{array}{l}24 \text { and } 96 \mathrm{~h} \\
\geq 0.005 \mathrm{mg} / \mathrm{L}\end{array}$ & $\begin{array}{l}\text { (Morales et al., 2020; } \\
\text { Park and Kwak, 2010; } \\
\text { Planelló et al.. 2008) }\end{array}$ \\
\hline 4-HB & $\equiv$ & $\begin{array}{l}24 \mathrm{~h} \\
\geq 0.1 \mathrm{mg} / \mathrm{L}\end{array}$ & $\equiv$ & $\begin{array}{l}24 \mathrm{~h} \\
\geq 0.1 \mathrm{mg} / \mathrm{L}\end{array}$ & \multicolumn{2}{|l|}{$\mathrm{N} / \mathrm{A}$} & $\equiv$ & $\begin{array}{l}24 \mathrm{~h} \\
\geq 0.1 \mathrm{mg} / \mathrm{L}\end{array}$ & (Ozáez et al., 2013) \\
\hline BP-3 & $\equiv$ & $\begin{array}{l}24 \mathrm{~h} \\
\geq 0.1 \mathrm{mg} / \mathrm{L}\end{array}$ & 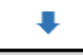 & $\begin{array}{l}24 \mathrm{~h} \\
10 \mathrm{mg} / \mathrm{L}\end{array}$ & \multicolumn{2}{|l|}{$\mathrm{N} / \mathrm{A}$} & $\equiv$ & $\begin{array}{l}24 \mathrm{~h} \\
\geq 0.1 \mathrm{mg} / \mathrm{L}\end{array}$ & (Ozáez et al., 2013) \\
\hline \multicolumn{10}{|l|}{ Group 3} \\
\hline EE & 1. & $\begin{array}{l}24 \mathrm{~h}, 5 \mathrm{mg} / \mathrm{L} \\
96 \mathrm{~h}, 0.5 \\
\mathrm{mg} / \mathrm{L} \\
\end{array}$ & \multicolumn{2}{|l|}{$\mathrm{N} / \mathrm{A}$} & \multicolumn{2}{|l|}{$\mathrm{N} / \mathrm{A}$} & \multicolumn{2}{|l|}{$N / A$} & This work \\
\hline \multicolumn{10}{|l|}{ Group 4} \\
\hline $\begin{array}{l}\text { OD- } \\
\text { PABA }\end{array}$ & 수 & $\begin{array}{l}24 \mathrm{~h} \\
1 \text { and } 10 \\
\mathrm{mg} / \mathrm{L}\end{array}$ & $\equiv$ & $\begin{array}{l}24 \mathrm{~h} \\
\geq 0.1 \mathrm{mg} / \mathrm{L}\end{array}$ & \multicolumn{2}{|l|}{$\mathrm{N} / \mathrm{A}$} & $\equiv$ & $\begin{array}{l}24 \mathrm{~h} \\
\geq 0.1 \mathrm{mg} / \mathrm{L}\end{array}$ & (Ozáez et al., 2013) \\
\hline OMC & 수 & $\begin{array}{l}24 \mathrm{~h} \\
1 \text { and } 10 \\
\mathrm{mg} / \mathrm{L}\end{array}$ & $\equiv$ & $\begin{array}{l}24 \mathrm{~h} \\
\geq 0.1 \mathrm{mg} / \mathrm{L}\end{array}$ & \multicolumn{2}{|l|}{$\mathrm{N} / \mathrm{A}$} & $\equiv$ & $\begin{array}{l}24 \mathrm{~h} \\
\geq 0.1 \mathrm{mg} / \mathrm{L}\end{array}$ & (Ozáez et al., 2013) \\
\hline OC & $\equiv$ & $\begin{array}{l}24 \mathrm{~h} \\
\geq 0.1 \mathrm{mg} / \mathrm{L}\end{array}$ & $\equiv$ & $\begin{array}{l}24 \mathrm{~h} \\
\geq 0.1 \mathrm{mg} / \mathrm{L}\end{array}$ & \multicolumn{2}{|l|}{$\mathrm{N} / \mathrm{A}$} & $\equiv$ & $\begin{array}{l}24 \mathrm{~h} \\
\geq 0.1 \mathrm{mg} / \mathrm{L}\end{array}$ & (Ozáez et al., 2013) \\
\hline BBP & 수 & $\begin{array}{l}24 \mathrm{~h} \\
\geq 0.1 \mathrm{mg} / \mathrm{L}\end{array}$ & $\equiv$ & $\begin{array}{l}24 \mathrm{~h} \\
0.01-1 \mathrm{mg} / \mathrm{L} \\
\text { (slight }\end{array}$ & $\mathrm{N} / \mathrm{A}$ & & $\equiv$ & $\begin{array}{l}24 \mathrm{~h} \\
\geq 10^{-5} \mathrm{mg} / \mathrm{L} \\
\text { (repression at } 10^{-6} \\
\text { mgll } \mathrm{L} \text { ). }\end{array}$ & $\begin{array}{l}\text { (Herrero et al., 2015; } \\
\text { Planelló et al., 2011) }\end{array}$ \\
\hline & 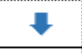 & $\begin{array}{l}48 \mathrm{~h} \\
\geq 10^{-6} \mathrm{mg} / \mathrm{L}\end{array}$ & & $\begin{array}{l}\text { activation at } \\
\geq 10 \mathrm{mg} / \mathrm{L})\end{array}$ & & & 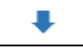 & $\begin{array}{l}48 \mathrm{~h} \\
10^{-6} \mathrm{mg} / \mathrm{L} \\
\end{array}$ & \\
\hline & 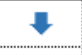 & $\begin{array}{l}24 \mathrm{~h} \\
100 \mathrm{mg} / \mathrm{L}\end{array}$ & & $24 \mathrm{~h}$ & & & 수 & $\begin{array}{l}24 \mathrm{~h} \\
50 \mathrm{mg} / \mathrm{L}\end{array}$ & (Herrero et al., 2017; \\
\hline DEHP & 7 & $\begin{array}{l}48,72 \text { and } 96 \\
\mathrm{~h} \\
\geq 10^{-6} \mathrm{mg} / \mathrm{L} \\
\end{array}$ & $\equiv$ & $\begin{array}{l}0.01-100 \\
\mathrm{mg} / \mathrm{L}\end{array}$ & $N / A$ & & 수 & $\begin{array}{l}96 \mathrm{~h} \\
\geq 0.5 \mathrm{mg}\end{array}$ & $\begin{array}{l}\text { Park and Kwak, 2010; } \\
\text { Planelló et al., 2011) }\end{array}$ \\
\hline Group 5 & & & & & & & & & \\
\hline NP & 순 & $\begin{array}{l}12 \text { and } 24 \mathrm{~h} \text {, } \\
0.05 \mathrm{mg} / \mathrm{L} ; \\
48 \text { and } 72 \mathrm{~h} \text {, } \\
0.01 \mathrm{mg} / \mathrm{L}\end{array}$ & $\mathrm{N} / \mathrm{A}$ & & $\mathrm{N} / \mathrm{A}$ & & 삼 & $\begin{array}{l}24 \text { and } 96 \mathrm{~h} \\
\geq 0.001 \mathrm{mg} / \mathrm{L}\end{array}$ & $\begin{array}{l}\text { (Nair and Choi, 2012; } \\
\text { Park and Kwak, }\end{array}$ \\
\hline & 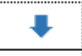 & $\begin{array}{l}24 \mathrm{~h} \\
0.1 \mathrm{mg} / \mathrm{L}\end{array}$ & & & & & 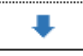 & $\begin{array}{l}24 \mathrm{~h} \\
0.1 \mathrm{mg} / \mathrm{L}\end{array}$ & \\
\hline 4-MBC & 1산 & $\begin{array}{l}24 \mathrm{~h} \\
\geq 0.1 \mathrm{mg} / \mathrm{L}\end{array}$ & $\equiv$ & $\begin{array}{l}24 \mathrm{~h} \\
\geq 0.1 \mathrm{mg} / \mathrm{L}\end{array}$ & $N / A$ & & $\equiv$ & $\begin{array}{l}24 \mathrm{~h} \\
\geq 0.1 \mathrm{mg} / \mathrm{L}\end{array}$ & (Ozáez et al., 2013) \\
\hline & $\equiv$ & $\begin{array}{l}12 \text { and } 24 \mathrm{~h} \\
0.250 \mathrm{mg} / \mathrm{L}\end{array}$ & & $\begin{array}{l}12,24 \text { and } \\
96 h\end{array}$ & & & & & \\
\hline $\mathrm{PCP}$ & - & $\begin{array}{l}96 \mathrm{~h} \\
0.250 \mathrm{mg} / \mathrm{L}\end{array}$ & $\equiv$ & $\begin{array}{l}96 \mathrm{~h} \\
\geq 0.025 \\
\mathrm{mg} / \mathrm{L}\end{array}$ & 수 & $\begin{array}{l}96 \mathrm{~h} \\
\geq 0.025 \\
\mathrm{ma} / \mathrm{L}\end{array}$ & 수 & $\begin{array}{l}96 \mathrm{~h} \\
\geq 0.025 \mathrm{mg} / \mathrm{L}\end{array}$ & (Morales et al., 2014) \\
\hline TCS & 1 & $\begin{array}{l}24 \mathrm{~h} \\
1 \mathrm{mg} / \mathrm{L} \\
\end{array}$ & 1 & $\begin{array}{l}24 \mathrm{~h} \\
0.010 \mathrm{mg} / \mathrm{L} \\
\end{array}$ & 순 & $\begin{array}{l}24 \mathrm{~h} \\
0.010 \mathrm{mg} / \mathrm{L} \\
\end{array}$ & 슨 & $\begin{array}{l}24 \mathrm{~h} \\
0.010 \mathrm{mg} / \mathrm{L} \\
\end{array}$ & $\begin{array}{l}\text { (Martínez-Paz et al., } \\
\text { 2017) }\end{array}$ \\
\hline Group 6 & & & & & & & & & \\
\hline & 술 & $\begin{array}{l}24 \mathrm{~h} \\
1 \times 10^{-6} \mathrm{mg} / \mathrm{L}\end{array}$ & 1 & $\begin{array}{l}24 \mathrm{~h} \\
1 \times 10^{-6} \mathrm{mg} / \mathrm{L}\end{array}$ & 순 & $\begin{array}{l}24 \mathrm{~h} \\
1 \times 10^{-6} \mathrm{mg} / \mathrm{L}\end{array}$ & 삼 & $\begin{array}{l}24 \mathrm{~h} \\
1 \times 10^{-5} \mathrm{mg} / \mathrm{L}\end{array}$ & (Morales et al., 2013) \\
\hline I010 & 수 & $96 \mathrm{~h}$ & 1 & $96 \mathrm{~h}$ & $\equiv$ & $96 \mathrm{~h}$ & $\equiv$ & $\begin{array}{l}96 \mathrm{~h} \\
\geq 1 \times 10^{-7} \mathrm{mg} / \mathrm{L}\end{array}$ & This work \\
\hline & & $\begin{array}{l}1 \times 10^{6} \text { and } \\
1 \times 10^{-5} \mathrm{mg} / \mathrm{L}\end{array}$ & & $\begin{array}{l}\geq 1 \times 10^{-7} \\
\mathrm{mg} / \mathrm{L}\end{array}$ & & $\begin{array}{l}\geq 1 \times 10^{-7} \\
\mathrm{mg} / \mathrm{L}\end{array}$ & & & \\
\hline
\end{tabular}

Symbols: $\equiv$ No significant effect; overexpression; downregulated; N/A: not available

Abbreviations: 20E, 20-hydroxyecdysone; EE, ethinyl oestradiol; PCP, pentachlorophenol; TCS, triclosan/5-chloro-2-(2,4-dichlorophenoxy)phenol; NP, p-nonylphenol; BPS, bisphenol S; BPA, bisphenol A; BPF, bisphenol F; BP-3, benzophenone-3; 4-HB, 4-hidroxybenzophenone; DEHP, di(2-ethylhexyl) phthalate; BBP, butyl benzyl phthalate; OMC, octyl-p-methoxycinnamate; OC, octocrylene; VZ, vinclozolin; SDZ, sulfadiazine; 4-MBC, 4-methylbenzylidene camphor; OD-PABA, octyl dimethyl-p-aminobenzoate; TBT, tributyltin; TBTO, bis(tributyltin) oxide

We differentiated six groups based on the physicochemical properties of the EDCs (considering SDZ, BpS and VZ in one unique group, marked as G1 and G1b in Fig. 6. Using this approach, we tried to simplify the analysis to get information that, combined with experimental data, could provide a useful classification of EDCs in advance and help to anticipate the putative results that can be obtained by other compounds. Thus, regarding these physicochemical properties, compounds more similar to $20 \mathrm{E}$ are those in group 1. Accordingly, it would be expected that they could mimic the $20 \mathrm{E}$ effect, just as it was observed in the experiments with VZ (Aquilino et al., 2016), where the sequential activation of EcR and E74 genes 
reproduces a similar response to the natural ecdysteroid (see Table 2). Responses to BPS and SDZ are compatible with these facts, but more experiments with longer exposure times are necessary for conformation. For all these compounds, the expected bioaccumulation potential and bioavailability are low (Figs. 4 and 5, as it was experimentally shown for SDZ (Xie et al., 2019) but, once inside the cell, they could interact with the EcR/USP heterodimer in a similar way to $20 \mathrm{E}$. We found a similar trend for BPF, but, on the contrary, there were not significant effects for exposure to 4-hidroxybenzophenone and BP-3, or they were observed at higher doses, as it is the case for bisphenol A. These compounds belong to group 2, where the expected bioaccumulation potential is increasing, but they are less similar to $20 \mathrm{E}$ in their properties. In group 4, there is a change in the trend, with $E c R$ being upregulated after octyl dimethylp-aminobenzoate and octyl-p-methoxycinnamate exposure and downregulated after BBP and DEHP exposure. Bioaccumulation potential for compounds in these groups are higher and are particularly great for DEHP. This phenomenon could be one of the causes of their effect as endocrine disruptors, but their physicochemical differences relative to $20 \mathrm{E}$ could be responsible for other mode(s) of action. Similarly, great bioavailability and bioaccumulation potential is expected for TBTO, but its chemical structure and properties could provide a basis for a different molecular mechanism of toxicity, as the upregulation of the usp gene indicate.

\section{Conclusion}

In summary, the ability of different chemical compounds to activate/repress transcription of the evaluated ecdysone cascade genes can be related to their endocrine disruptive effects and reveal different underlying molecular mechanisms of toxicity. Being able to classify chemicals based on effects they have at the molecular level helps to develop rationale, cost-effective and comprehensive testing approaches to evaluate environmental hazards. A previous classification of EDCs based on their physicochemical properties seems to be of interest to understand those effects. For any future work, it should be preferable assess the effect of short-term ( $24 \mathrm{~h})$ and long-term $(96 \mathrm{~h})$ treatment and three different sub-lethal dosages for each considered EDCs to identify the different patterns of changes on the $E C R$ transcription and to get a more complete view.

\section{Declarations}

Author contribution All authors contributed to the study conception and design. MF: literature search and data analysis, writing - review and editing. RMF: conceptualization, methodology TBTO, writing - review and editing. PMP: conceptualization, methodology NP and TBTO. EC: conceptualization, methodology EE. JLMG: funding acquisition, investigation reviewing and editing. MM: conceptualization, methodology NP and TBTO, investigation reviewing and editing, writing-original draft preparation, supervision.

Funding This work was supported by the Programa Estatal de I+D+i Orientada a los Retos de la Sociedad (Spain), grant RTI2018-094598-B-I00, from the Ciencias y Tecnologías Medioambientales programme.

Ethics approval Not applicable. 
Consent to participate Not applicable.

Consent for publication Not applicable.

Data availability All data generated or analyzed during this study are included in this published article

Competing interests The authors declare no competing interests.

\section{References}

1. Aquilino, M., Sánchez-Argüello, P., Martínez-Guitarte, J.-L., 2016. Vinclozolin alters the expression of hormonal and stress genes in the midge Chironomus riparius. Aquat. Toxicol. Amst. Neth. 174, 179187. https://doi.org/10.1016/j.aquatox.2016.03.001

2. American Society for Materials Testing, 2006. Test Method for Measuring the Toxicity of SedimentAssociated Contaminants with Freshwater Invertebrates. Book of Standards. ASTM International, Philadelphia. https://doi.org/10.1520/E1706-20

3. Ashburner M. 1974. Sequential gene activation by ecdysone in polytene chromosomes of Drosophila melanogaster: II. The effects of inhibitors of protein synthesis. Developmental Biology. 39, 141-157 https://doi.org/10.1016/S0012-1606(74)80016-3

4. Bhal, S. Lipophilicity Descriptors: Understanding When to Use Log P \& Log D 4. ACD/Labs Application Note. https://www.acdlabs.com/download/app/physchem/logp_vs_logd.pdf (accessed $12^{\text {th }}$ October 2020).

5. Bunce, C.M., Campbell, M.J., 2010. Nuclear Receptors: Current Concepts and Future Challenges. Dordrecht, Springer Science \& Business Media. https://doi.org/10.1007/978-90-481-3303-1.

6. Cuvillier-Hot, V., Lenoir, A., 2020. Invertebrates facing environmental contamination by endocrine disruptors: novel evidences and recent insights. Mol. Cell. Endocrinol. 504, 110712. https://doi.org/10.1016/j.mce.2020.110712

7. Dhadialla, T.S., Retnakaran, A., Smagghe, G., 2005. Insect growth- and development-disrupting insecticides, in: L. I. Gilbert, I. Kostas, and S. S. Gill (Eds.), Comprehensive Insect Molecular Science, Volume 6: Control (pp. 55-115). Oxford, UK: Pergamon; Elsevier.

8. Hellemans, J., Mortier, G., De Paepe, A., Speleman, F., Vandesompele, J., 2007. Qbase relative quantification framework and software formanagement and automated analysis of real-time quantitative PCR data. Genome Biol. 8:R19. https://doi.org/10.1186/gb-2007-8-2-r19.

9. Herrero, Ó., Aquilino, M., Sánchez-Argüello, P., Planelló, R., 2018. The BPA-substitute bisphenol S alters the transcription of genes related to endocrine, stress response and biotransformation pathways in the aquatic midge Chironomus riparius (Diptera, Chironomidae). PloS One 13, e0193387. https://doi.org/10.1371/journal.pone.0193387

10. Herrero, Ó., Morcillo, G., Planelló, R., 2017. Transcriptional deregulation of genetic biomarkers in Chironomus riparius larvae exposed to ecologically relevant concentrations of di(2-ethylhexyl) phthalate (DEHP). PLoS One 12, e0171719. https://doi.org/10.1371/journal.pone.0171719 
11. Herrero, Ó., Planelló, R., Morcillo, G., 2015. The plasticizer benzyl butyl phthalate (BBP) alters the ecdysone hormone pathway, the cellular response to stress, the energy metabolism, and several detoxication mechanisms in Chironomus riparius larvae. Chemosphere 128, 266-277. https://doi.org/10.1016/j.chemosphere.2015.01.059

12. Huet, F., Ruiz, C., Richards, G., 1995. Sequential gene activation by ecdysone in Drosophila melanogaster: the hierarchical equivalence of early and early late genes. Dev. Camb. Engl. 121, 1195-1204.

13. Karim, F.D., Thummel, C.S., 1992. Temporal coordination of regulatory gene expression by the steroid hormone ecdysone. EMBO J. 11, 4083-4093. https://doi.org/10.1002/j.1460-2075.1992.tb05501.x

14. Katagi, T., Tanaka, H., 2016. Metabolism, bioaccumulation, and toxicity of pesticides in aquatic insect larvae. J. Pestic. Sci. 41, 25-37. https://doi.org/10.1584/jpestics.D15-064

15. Kim, H.J., Koedrith, P., Seo, Y.R., 2015. Ecotoxicogenomic approaches for understanding molecular mechanisms of environmental chemical toxicity using aquatic invertebrate, Daphnia model organism. Int. J. Mol. Sci. 16, 12261-12287. https://doi.org/10.3390/ijms160612261

16. Koelle, M.R., Talbot, W.S., Segraves, W.A., Bender, M.T., Cherbas, P., Hogness, D.S., 1991. The Drosophila EcR gene encodes an ecdysone receptor, a new member of the steroid receptor superfamily. Cell 67, 59-77. https://doi.org/10.1016/0092-8674(91)90572-g

17. Lai, K.M., Scrimshaw, M.D., Lester, J.N., 2002. Prediction of the bioaccumulation factors and body burden of natural and synthetic estrogens in aquatic organisms in the river systems. Sci. Total Environ. 289, 159-168. https://doi.org/10.1016/S0048-9697(01)01036-1

18. Lezzi, M., Bergman, T., Mouillet, J.-F., Henrich, V.C., 1999. The ecdysone receptor puzzle. Arch. Insect Biochem. Physiol. 41, 99-106. https://doi.org/10.1002/(SICI)1520-6327(1999)41:2<99::AIDARCH6>3.0.CO;2-W

19. Martínez-Guitarte, J.L., Planelló, R., Morcillo, G., 2007. Characterization and expression during development and under environmental stress of the genes encoding ribosomal proteins $\mathrm{L} 11$ and L13 in Chironomus riparius. Comp. Biochem. Physiol. B Biochem. Mol. Biol. 147, 590-596. https://doi.org/10.1016/j.cbpb.2007.03.015

20. Martínez-Paz, P., Morales, M., Martín, R., Martínez-Guitarte, J.L., Morcillo, G., 2014. Characterization of the small heat shock protein Hsp27 gene in Chironomus riparius (Diptera) and its expression profile in response to temperature changes and xenobiotic exposures. Cell Stress Chaperones 19, 529-540. https://doi.org/10.1007/s12192-013-0479-y

21. Martínez-Paz, P., Morales, M., Martínez-Guitarte, J.L., Morcillo, G., 2012. Characterization of a cytochrome P450 gene (CYP4G) and modulation under different exposures to xenobiotics (tributyltin, nonylphenol, bisphenol A) in Chironomus riparius aquatic larvae. Comp. Biochem. Physiol. Part C Toxicol. Pharmacol. 155, 333-343. https://doi.org/10.1016/j.cbpc.2011.10.001

22. Martínez-Paz, P., Morales, M., Urien, J., Morcillo, G., Martínez-Guitarte, J.L., 2017. Endocrine-related genes are altered by antibacterial agent triclosan in Chironomus riparius aquatic larvae. Ecotoxicol. Environ. Saf. 140, 185-190. https://doi.org/10.1016/j.ecoenv.2017.02.047 
23. Metsalu, T., Vilo, J., 2015. ClustVis: a web tool for visualizing clustering of multivariate data using principal component analysis and heatmap. Nucleic Acids Res. 43, W566-W570. https://doi.org/10.1093/nar/gkv468

24. Molinspiration Cheminformatics free web services, n.d. https://www.molinspiration.com (accessed $12^{\text {th }}$ October 2020).

25. Morales, M., de la Fuente, M., Martín-Folgar, R., 2020. BPA and its analogues (BPS and BPF) modify the expression of genes involved in the endocrine pathway and apoptosis and a multi drug resistance gene of the aquatic midge Chironomus riparius (Diptera). Environ. Pollut. 114806. https://doi.org/10.1016/j.envpol.2020.114806

26. Morales, M., Martínez-Paz, P., Martín, R., Planelló, R., Urien, J., Martínez-Guitarte, J.L., Morcillo, G., 2014. Transcriptional changes induced by in vivo exposure to pentachlorophenol (PCP) in Chironomus riparius (Diptera) aquatic larvae. Aquat. Toxicol. 157, 1-9. https://doi.org/10.1016/j.aquatox.2014.09.009

27. Morales, M., Martínez-Paz, P., Ozáez, l., Martínez-Guitarte, J.L., Morcillo, G., 2013. DNA damage and transcriptional changes induced by tributyltin (TBT) after short in vivo exposures of Chironomus riparius (Diptera) larvae. Comp. Biochem. Physiol. Part C Toxicol. Pharmacol. 158, 57-63. https://doi.org/10.1016/j.cbpc.2013.05.005

28. Nair, P.M.G., Choi, J., 2012. Modulation in the mRNA expression of ecdysone receptor gene in aquatic midge, Chironomus riparius upon exposure to nonylphenol and silver nanoparticles. Environ. Toxicol. Pharmacol. 33, 98-106. https://doi.org/10.1016/j.etap.2011.09.006

29. Nair, P.M.G., Park, S.Y., Choi, J., 2013. Evaluation of the effect of silver nanoparticles and silver ions using stress responsive gene expression in Chironomus riparius. Chemosphere 92, 592-599. https://doi.org/10.1016/j.chemosphere.2013.03.060

30. Nakagawa, Y., Henrich, V.C., 2009. Arthropod nuclear receptors and their role in molting. FEBS J. 276, 6128-6157. https://doi.org/10.1111/j.1742-4658.2009.07347.x

31. National Research Council, 2014. A Framework to Guide Selection of Chemical Alternatives. The National Academies Press, Washington, D.C.. https://doi.org/10.17226/18872

32. Organization for Economic Co-operation and Development, 2004. Test No. 218: Sediment-Water Chironomid Toxicity Using Spiked Sediment, OECD Guidelines for the Testing of Chemicals, Section 2. OECD Publishing, Paris.

33. Organization for Economic Co-operation and Development, 2010. Test No. 233: Sediment-Water Chironomid Life-Cycle Toxicity Test Using Spiked Water or Spiked Sediment, OECD Guidelines for the Testing of Chemicals, Section 2. OECD Publishing, Paris.

34. Organization for Economic Co-operation and Development, 2011. Test No. 235: Chironomus sp., Acute Immobilisation Test, OECD Guidelines for the Testing of Chemicals, Section 2. OECD Publishing, Paris.

35. Ozáez, I., Aquilino, M., Morcillo, G., Martínez-Guitarte, J.-L., 2016. UV filters induce transcriptional changes of different hormonal receptors in Chironomus riparius embryos and larvae. Environ. Pollut. 
Barking Essex 1987 214, 239-247. https://doi.org/10.1016/j.envpol.2016.04.023

36. Ozáez, l., Martínez-Guitarte, J.L., Morcillo, G., 2013. Effects of in vivo exposure to UV filters (4-MBC, OMC, BP-3, 4-HB, OC, OD-PABA) on endocrine signaling genes in the insect Chironomus riparius. Sci. Total Environ. 456-457, 120-126. https://doi.org/10.1016/j.scitotenv.2013.03.081

37. Ozáez, I., Martínez-Guitarte, J.L., Morcillo, G., 2014. The UV filter benzophenone 3 (BP-3) activates hormonal genes mimicking the action of ecdysone and alters embryo development in the insect Chironomus riparius (Diptera). Environ. Pollut. 192, 19-26. https://doi.org/10.1016/j.envpol.2014.04.038

38. Park, K., Kwak, I.-S., 2010. Molecular effects of endocrine-disrupting chemicals on the Chironomus riparius estrogen-related receptor gene. Chemosphere 79, 934-941.

https://doi.org/10.1016/j.chemosphere.2010.03.002

39. Planelló, R., Herrero, Ó., Gómez-Sande, P., Ozáez, I., Cobo, F., Servia, M.J., 2015. Ecdysone-related biomarkers of toxicity in the model organism Chironomus riparius: stage and sex-dependent variations in gene expression profiles. PLoS One 10. https://doi.org/10.1371/journal.pone.0140239

40. Planelló, R., Herrero, O., Martínez-Guitarte, J.L., Morcillo, G., 2011. Comparative effects of butyl benzyl phthalate (BBP) and di(2-ethylhexyl) phthalate (DEHP) on the aquatic larvae of Chironomus riparius based on gene expression assays related to the endocrine system, the stress response and ribosomes. Aquat. Toxicol. 105, 62-70. https://doi.org/10.1016/j.aquatox.2011.05.011

41. Planelló, R., Martínez-Guitarte, J.L., Morcillo, G., 2007. Ribosomal genes as early targets of cadmiuminduced toxicity in Chironomus riparius larvae. Sci. Total Environ. 373, 113-121. https://doi.org/10.1016/j.scitotenv.2006.10.038

42. Planelló, R., Martínez-Guitarte, J.L., Morcillo, G., 2008. The endocrine disruptor bisphenol A increases the expression of HSP70 and ecdysone receptor genes in the aquatic larvae of Chironomus riparius. Chemosphere 71, 1870-1876. https://doi.org/10.1016/j.chemosphere.2008.01.033

43. Planelló, R., Martínez-Guitarte, J.L., Morcillo, G., 2010. Effect of acute exposure to cadmium on the expression of heat-shock and hormone-nuclear receptor genes in the aquatic midge Chironomus riparius. Sci. Total Environ. 408, 1598-1603. https://doi.org/10.1016/j.scitotenv.2010.01.004

44. Poynton, H.C., Vulpe, C.D., 2009. Ecotoxicogenomics: emerging technologies for emerging contaminants. J. Am. Water Resour. Assoc. 45, 83-96. https://doi.org/10.1111/j.17521688.2008.00291.x

45. Shirai, H., Kamimura, M., Yamaguchi, J., Imanishi, S., Kojima, T., Fujiwara, H., 2012. Two adjacent cisregulatory elements are required for ecdysone response of ecdysone receptor (EcR) B1 transcription. PLoS One 7, e49348. https://doi.org/10.1371/journal.pone.0049348

46. Tetko, I.V., Gasteiger, J., Todeschini, R., Mauri, A., Livingstone, D., Ertl, P., Palyulin, V.A., Radchenko, E.V., Zefirov, N.S., Makarenko, A.S., Tanchuk, V.Yu., Prokopenko, V.V., 2005. Virtual computational chemistry laboratory - design and description. J. Comput. Aided Mol. Des. 19, 453-463. https://doi.org/10.1007/s10822-005-8694-y 
47. United States Environmental Protection Aggency, 2020. Estimation Programs Interface Suite ${ }^{T M}$ for Microsoft@ Windows, v 4.11. United States Environmental Protection Agency, Washington, DC.

48. Uyehara, C.M., McKay, D.J., 2019. Direct and widespread role for the nuclear receptor EcR in mediating the response to ecdysone in Drosophila. Proc. Natl. Acad. Sci. 116, 9893-9902. https://doi.org/10.1073/pnas.1900343116

49. Xie, Z., Tang, J., Wu, X., Fan, S., Cheng, H., Li, X., Hua, R., 2019. Bioconcentration and ecotoxicity of sulfadiazine in the aquatic midge Chironomus riparius. Environ. Toxicol. Pharmacol. 66, 69-74. https://doi.org/10.1016/j.etap.2018.12.021

50. Yao, T., Forman, B.M., Jiang, Z., Cherbas, L., Chen, J.-D., McKeown, M., Cherbas, P.T., Evans, R.M., 1993. Functional ecdysone receptor is the product of EcR and Ultraspiracle genes. Nature. https://doi.org/10.1038/366476a0

51. Zhang, Y., Lorsbach, B.A., Castetter, S., Lambert, W.T., Kister, J., Wang, N.X., Klittich, C.J.R., Roth, J., Sparks, T.C., Loso, M.R., 2018. Physicochemical property guidelines for modern agrochemicals. Pest Manag. Sci. https://doi.org/10.1002/ps.5037

\section{Supplementary File}

Supplemental Material file is not available with this version.

\section{Figures}



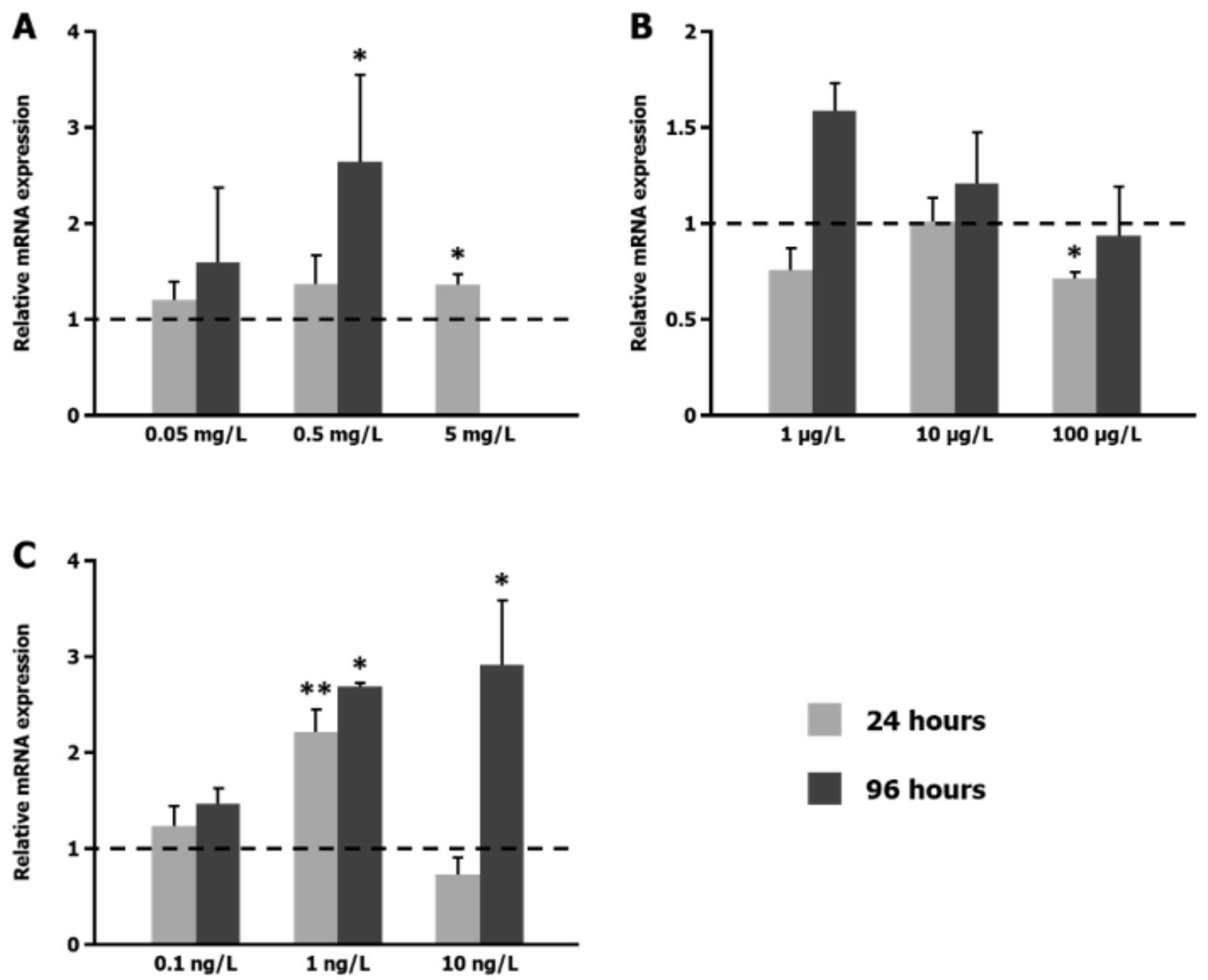

\section{4 hours}

\section{6 hours}

Figure 1

Effect of ethinyl oestradiol (A), p-nonylphenol (B) and bis(tributyltin) oxide (C) exposure on EcR gene expression. The graphs present the relative mRNA levels, measured by real-time PCR with primers and reference genes indicated in section 2.3, after 24 and 96 h exposure, relative to untreated control larvae, for which the expression level was set to 1 . 




Figure 2

Effect of p-nonylphenol exposure on ERR gene expression. The graph presents the relative ERR mRNA expression, measured by real-time PCR with primers and reference genes indicated in section 2.3, after 24 and $96 \mathrm{~h}$ exposure, relative to untreated control larvae for which the expression level was set to 1.
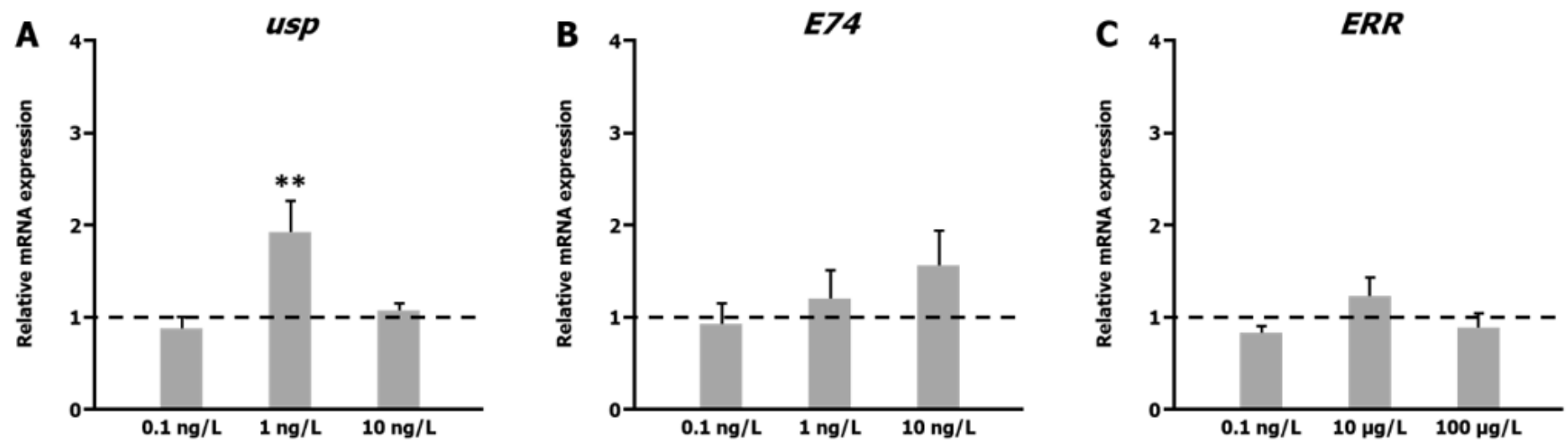

Figure 3

Effect of bis(tributyltin) oxide (C) exposure on usp, E74 and ERR gene expression. The graphs present the relative usp (A), E74 (B) and ERR (C) mRNA levels, measured by real time PCR with primers and reference genes indicated in section 2.3, after $96 \mathrm{~h}$ exposure to TBTO, relative to untreated control larvae, for which the expression level was set to 1 . 


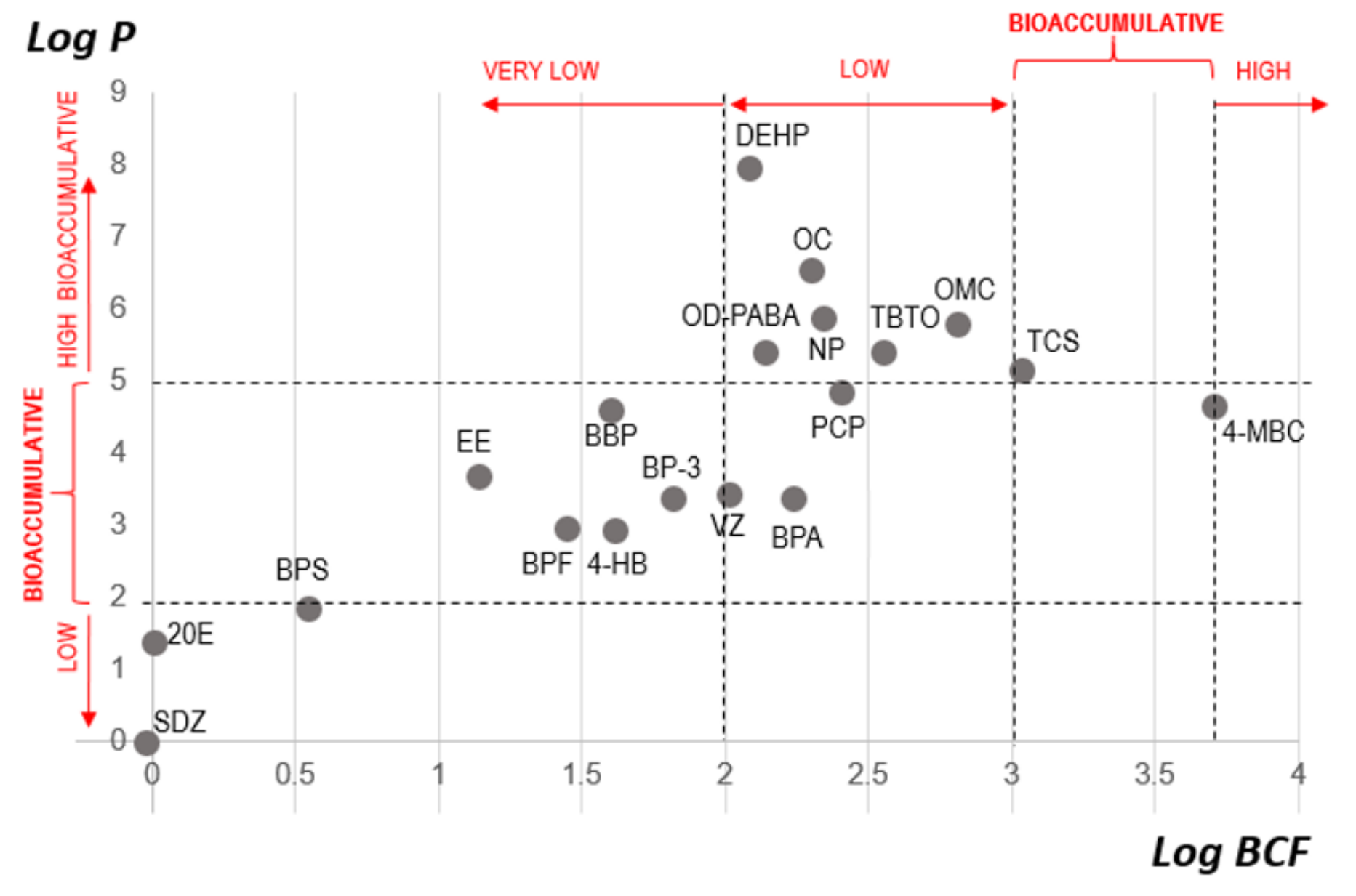

Figure 4

Bioaccumulation potential. Log bioconcentration factor (BCF, defined as the ratio of the amount of chemical in an aquatic organism to the amount of chemical in the water under conditions of equilibrium) versus miLogP, where $\mathrm{P}$ is the octanol-water partition coefficient. Both indicators have been calculated by Molinspiration (https://www.molinspiration.com). 


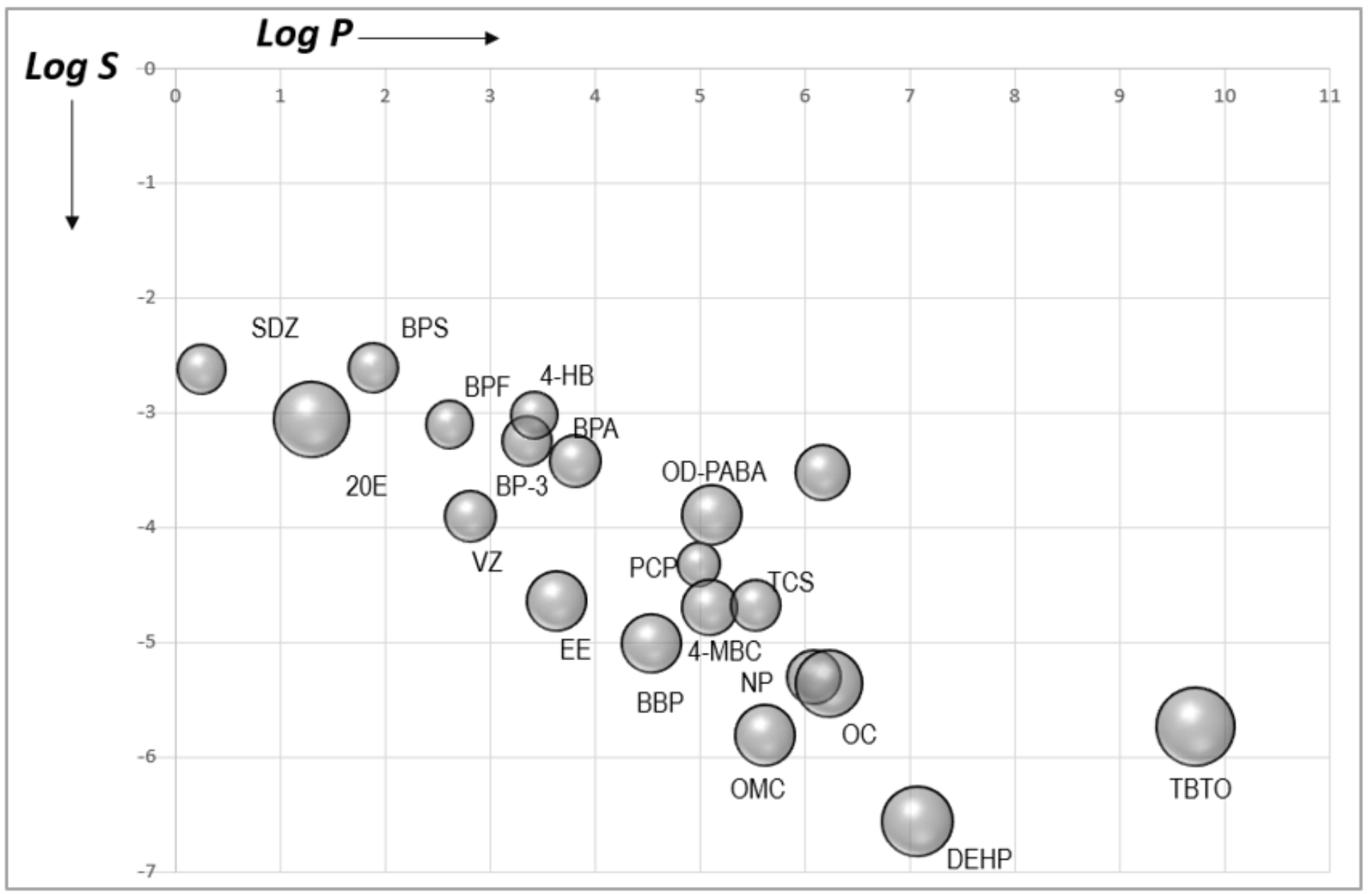

\section{Figure 5}

Ghose-Crippen octanol-water partition coefficient (logP) (lipophilicity) versus aqueous solubility (log S); both descriptors calculated by eDragon v1.0 (Tetko et al., 2005). The bubble size represents the molecular volume calculated by Molinspiration (https://www.molinspiration.com). 


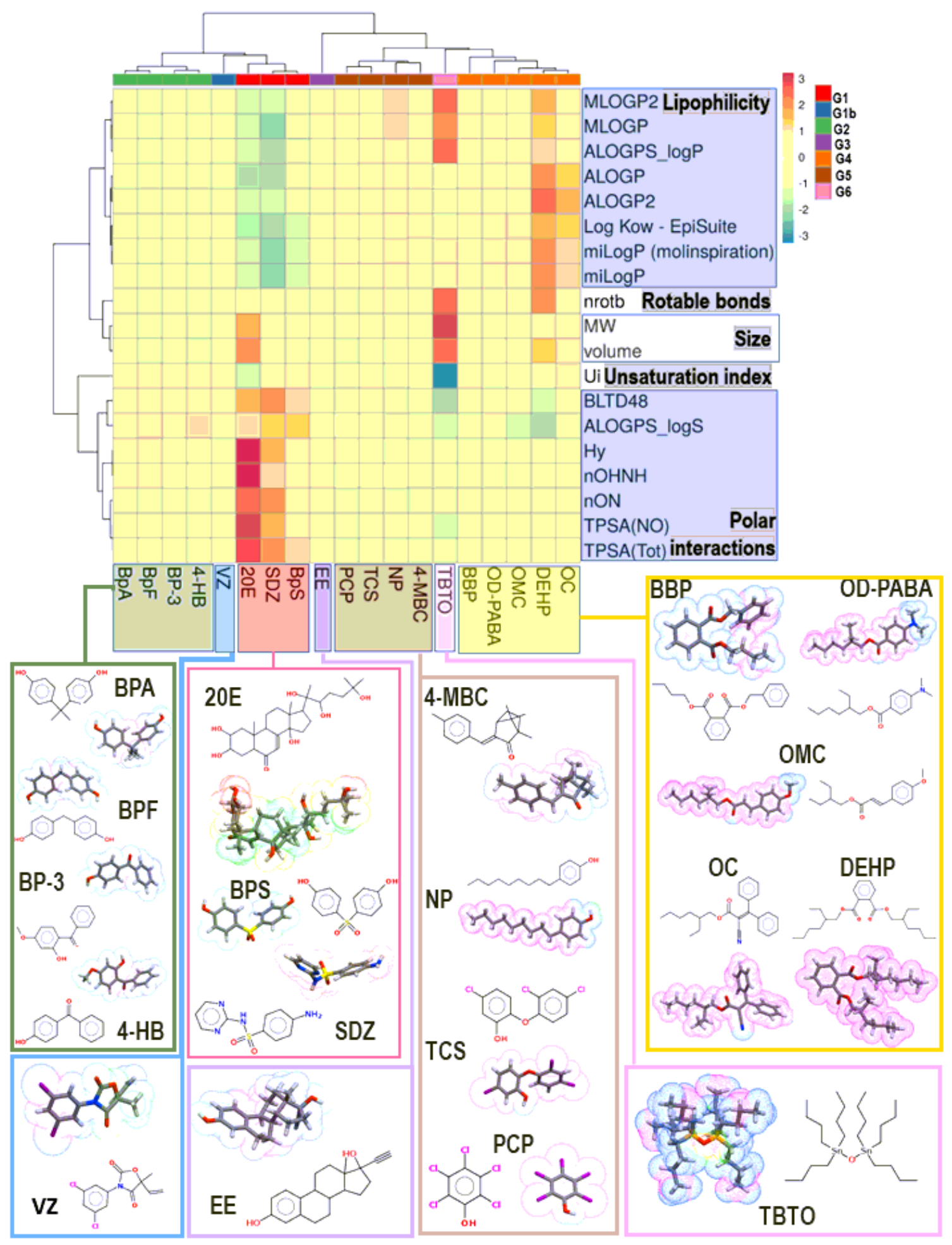

\section{Figure 6}

Heatmap showing colour codes for the value of the analysed descriptors. Rows are centred; unit variance scaling is applied to rows. Imputation is used to estimate missing values. Both rows and columns are clustered using correlation distance and average linkage. Molecular structures clustered in relation to their physicochemical properties showing molecular lipophilicity potential (MLP) on the molecular surface. Hydrophobic regions are highlighted by violet and blue, and hydrophilic regions are highlighted in 
orange and red. We calculated MLP from atomic hydrophobicity contributions with Molinspiration Cheminformatics free web services (https://www.molinspiration.com) and Molinspiration Galaxy 3D Structure Generator v2018.01_beta. 